\title{
Research on Central Asian Chinese Media Against the Background of the Belt and Road Initiative*
}

\author{
Nan Dai \\ Shanghai University of Political Science and Law \\ Shanghai, China 201701
}

\begin{abstract}
Taking the Chinese media communicated in Central Asia as the research object, this paper explores the development pattern and communication situation of Chinese media in Central Asia by combing the development of Chinese media in Central Asian countries under the Belt and Road Initiative. The purpose is to keep an eye on the communication function of Central Asian Chinese media along the "New Silk Road" and its role in the construction and communication of Chinese national image.
\end{abstract}

Keywords-the Belt and Road Initiative; Central Asian Chinese Media; communication

\section{INTRODUCTION}

Since the beginning of the 21st century, especially since $\mathrm{Xi}$ Jinping came to power and served as the General Secretary, China has further integrated into the world with global governance concepts and strategic thinking. The Chinese discourse power and China's international communication ability are both given the top priority in the research on international communication and foreign communication under the new situation. In 2013, Chinese President Xi Jinping made a speech in Kazakhstan and proposed to jointly construct the "Silk Road Economic Belt" (also known as the "New Silk Road"). Later, President Xi Jinping proposed an initiative to build the "21st Century Maritime Silk Road".

Central Asia is the only place connected the east and west ends of the Eurasian continent, and is also the core area of the "Silk Road Economic Belt". Central Asia has gathered about 600,000 overseas Chinese, and [1] plays an important role in the exchanges between Central Asia and China. Overseas Chinese communities have "three treasures", namely overseas Chinese groups, overseas Chinese schools and overseas Chinese media. In recent years, in the context of the Belt and Road Initiative, China's contacts with Central Asia have become increasingly close, and Chinese media have also emerged in Central Asia.

\section{LITERATURE REVIEW OF RESEARCHES ON CENTRAL ASIAN CHINESE MEDIA}

According to the existing result of research on overseas

*Fund: The results of this research are funded by the Research Fund Project of China National Institute for SCO International Exchange and Judicial Cooperation (Project No.: 18SHJD031).
Chinese media, Chinese media in Central Asia is an emerging phenomenon and also a field less concerned in existing academic researches. Earlier researches show that the five Central Asian countries "have no Chinese newspapers" and "new media is in the initial stage" [2]. In recent years, the five Central Asian countries have begun to appear in Chinese newspapers issued in local place and Chinese new media. However, due to the small scale and new publication, the research on this new phenomenon has been less carried out.

At present, the studies on Chinese media in Central Asia are more concerned in the researches on Xinjiang's communication to Central Asia, mainly in the results of some scholars in Xinjiang. The researches focus on summarizing Xinjiang's practical operation and propaganda experience in communication to Central Asia. For example, the paper "Status Quo, Problems and Strategies of Xinjiang Radio and Television's Communication to Central Asia" written by Luo Bin from Xinjiang University of Finance \& Economics, the paper "Analysis on the Strategies of Xinjiang Media's Communication to Central Asia" written by Zhao Lifang and by GuLimila Yalikun from Minzu University of China, Central University for Nationalities are the result of researches on Xinjiang's communication to Central Asia. In addition, there are also some researches on foreign communication concerned Central Asia, such as $\mathrm{He}$ Xiaoxiao's "The Status Quo and Countermeasures of China's Network Communication to Countries along the 'Belt and Road': Taking the Five Central Asian Countries as an Example" analyzes the development status of Central Asian Network Media and Chinese central network media's objective communication practice; the "other image: the Belt and Road and Chinese image communication - taking the Russian region as an example" published by Luo Bing in 2017 also covers researches on CCTV Chinese international channel and the overseas edition of People's Daily in addition to researches on the audience in Central Asia and Russian media in China.

\section{COMMUNICATION ENVIRONMENT OF CENTRAL ASIAN CHINESE MEDIA}

\section{A. Background of the Belt and Road Initiative}

The communication environment is the living and development environment of media, and is the sum of many 
is not free. Uzbekistan and Tajikistan's media are strictly controlled by the state and are seriously Russianized; new media is not ready-made, the network speed is slow, and the coverage is small. [5]

Although the development of media and communication levels of various countries shows an uneven situation due to the difference in national conditions and technological capabilities, the rise of the Internet and new media is an irresistible and negligible trend for all countries. At present in Kazakhstan and Kyrgyzstan, network has surpassed TV and become the medium mostly used by the audience. Moreover, compared with the history of Chinese media development in other regions, the new phenomenon of Chinese media development in Central Asia is precisely emerged and developed in the context of globalization and new media. Therefore, the involvement of new information technology and new media is an important environmental factor in the development of Chinese media in Central Asia.

\section{COMMUNiCATION PATTERNS OF CENTRAL ASIAN CHINESE MEDIA}

In recent years, in the context of the Belt and Road Initiative, China's contacts with Central Asia have become increasingly close, and Chinese media have also emerged in Central Asia. In Tajikistan, the first Chinese newspaper "New Silk Road" was born in 2016. In Kazakhstan, there are the "Kazakhstan Overseas Chinese News" and "Today's Silk Road", wherein "Today's Silk Road" is the first newspaper in the country including Kazakh, Russian, Chinese and Donggan language versions. In Kyrgyzstan, there are the "Central Asian Overseas Chinese News" and the "New Observations of Silk Road". Among them, the "New Observations of Silk Road" newspaper was published and issued by Kyrgyzstan Silk Road Cultural Development Co., Ltd., has Russian and Chinese versions, and with a circulation of about 18,000 copies per issue. At the same time, the newspaper also actively created a wide media platform. In 2016, the "New Observations of Silk Road" Internet platform was launched, focusing on serving Central Asian overseas Chinese, Chinese businessmen, Confucius Institutes and international students, Chinese-funded enterprises, and short-term Chinese visitors and local mainstream society. Later, the newspaper also successively launched new media platforms such as the "New Observations of Silk Road" series of WeChat Official Account and the like new media platforms; and in the beginning of 2019, it also created Instagram new media. According to the latest statistics, the number of fans reached 38,000 to the end of July, 2019. In the social media of the country only having a population of more than 6 million, Kyrgyzstan's social media can be described as a new force suddenly rises [6]. It can be said that the "New Silk Road" newspaper has opened up a new development model. While exerting the geographical advantages, it has also broken through the geographical restrictions of communication and built an information platform between China and Central Asian countries in the form of multimedia matrix.

In addition, with the gradual improvement of China's foreign communication system, some national media in 
constructs the image of the country, and the foreign media builds the image of other country, the domestic media and international media jointly build the image of a country. [8] Due to the unique geographical advantages, overseas Chinese media has its own unique advantages in the shaping and communication of China's national image. Studies have shown that overseas Chinese media plays a role of coconstructing China's national image. [9]

Against the background of the Belt and Road Initiative, China's communication with Central Asian countries in economy and culture become closer. In this process, Chinese media, as a communication link and bridge, also constantly conveys the development course of China to the Central Asian overseas Chinese community and Central Asian society. Many major events relevant to China such as the Import and Export Expo, the 70th anniversary of the founding of the People's Republic of China can form a common concern in the Chinese media in Central Asia.

\section{CONCLUSION}

In 2015, Cheng Manli, a scholar who has long been committed to overseas Chinese media research, proposed that in order to recognize the function and status of overseas Chinese media, researchers should make research from a global perspective based on strategic communication, "adjust the concept and strengthen their acquaintances consciousness [10]", let new immigrants and the media run by them "play a role and create synergy" in the Chinese government's global strategic thinking. This view is precisely the logical basis for this research, and also provides a new research perspective for overseas Chinese media research under the new situation.

The new international political pattern and the overseas Chinese ecological environment, new communication concepts and strategic thinking, new media and cultural environment have injected new vitality into the development of overseas Chinese media. As the communicator of Chinese story and the loudspeaker of Chinese voice, Central Asian Chinese Media has shaped and disseminated the national image of China to Central Asian region and even the international community based on its unique geographical advantages and communication context.

\section{REFERENCES}

[1] Chen Zhiming. One Belt, One Road, Central Asia and the Study of the Chinese Overseas [J]. Qinghai Journal of thnology, 2018 (1). (in Chinese)

[2] Peng Weibu. Overseas Chinese media's construction of the "Belt and Road" information interconnection mechanism and its implementation path [J]. Global Communication, 2017(1). (in Chinese)

[3] Hu Bangsheng. Kazakhstan media ecology and its characteristics [J] International Communications, 2017(7). (in Chinese)

[4] Jing Deming, Wang Youwen. The Characteristics and Opportunities of Xinjiang's Dissemination to Central Asian Countries - From the Perspective of Co-building the Silk Road Economic Belt [J]. The Press, 2017(2). (in Chinese)

[5] Li Wei. Construction of News Cooperation Alliances of China Russia and Central Asia under the Framework of the Belt and Road Initiative[J]. Chinese Culture Research, 2018(4). (in Chinese) 
[6] Tao Shuanke. The director of the Kyrghyzstan parliamentary press center praised the "New Observation of Silk Road" newspaper [N]. New Observation of Silk Road. 2019 (8). (in Chinese)

[7] $\mathrm{Xu}$ Xiaoge. The issue of national image in international news communication. Journalism Communication, 1996(2). (in Chinese)

[8] Liu Xiaoyan. Thinking on shaping of State images by the media [J]. Chinese Journal of International Communication, 2002 (2). (in Chinese)

[9] Han Jie. Comparison of overseas Chinese media and domestic media's reports on construction of national image $[\mathrm{J}]$. The Press, 2016(2). (in Chinese)

[10] Cheng Manli. Re-examine overseas Chinese media with China's global strategic thinking [J]. International Communications, 2015(10). (in Chinese) 